\title{
LOCAL KNOWLEDGE ON THE LOCAL OWNERSHIP PRINCIPLE IN SERBIA
} UDC 342.72/.73(497.11)

\author{
Zorica Mršević ${ }^{1}$, Svetlana Janković ${ }^{2}$ \\ ${ }^{1}$ Institute of Social Sciences, Belgrade, Republic of Serbia \\ ${ }^{2}$ Strategic Research Institute, Belgrade, Republic of Serbia
}

\begin{abstract}
This paper presents the way of functioning and implementation of the local ownership principle in situations where the support of local knowledge during the process of establishment of gender equality mechanisms is lacking. Gender equality mechanisms were part of the package of international organizations' influence over the process of democratic institutional reform in Serbia. The whole process is based on a numerous international documents that incite and justify the establishment of institutional mechanisms for gender equality at all levels of government: national, regional and local. The experience and knowledge of Western countries has contributed most to the process of formulating gender equality mechanisms and their subsequent functioning in Serbia. The lack of local knowledge production regarding the essence and role of the local ownership principle in the creation of gender equality institutions is permanent in Serbia. The concept of "learning sites", i.e. external actors becoming familiar with an internal situation has barely been applied in Serbia. The so-called "glocal" period of deep intermingling of both local and global elements did not happen. The authors argue that there was no essential "localization" of gender equality mechanisms based on domestic knowledge, and that both foreign and domestic actors are responsible for this situation: External actors because, apart from Western theory and experience, they are unaware of and/or neglect local knowledge, regardless of whether they consider it non-existent or inferior in comparison to the knowledge of Western countries. At the same time, domestic actors became quickly satisfied with the comfortable position of secondary lead stakeholders, with a role of transmitters and users of foreign concepts. They did not take advantage of the opportunities provided by the local ownership principle and did not pretend to take on either the role of creators or of relevant knowledge holders of policy-based public policies and practices.
\end{abstract}

Key words: international actors, local ownership principle, learning sites, humanitarian industry, gender equality mechanisms in Serbia, transversal policy.

Received April $4^{\text {th }}, 2018 /$ Accepted August $7^{\text {th }}, 2018$

Corresponding author: Zorica Mršević, PhD, Institute of Social Sciences, Kraljice Natalije 45, 11000 Belgrade, Republic of Serbia

E-mail: zmrsevic@idn.org.rs 


\section{INTRODUCTION}

The local ownership principle has the primary goal of reducing the domination of external partners on projects financed through cooperation and activities aimed at development and peace building. This principle can work effectively to change the (im)balance of power in favour of local actors, but only if both external and domestic actors are aware of its essence and accept its application.

This principle began to be implemented by international organizations in the $1980 \mathrm{~s}$ and 1990s and, to date, has become part of the standard 'package' of foreign development assistance in numerous countries. The local ownership concept began to be widely implemented as of its recognition as a key concept in 1996 by the Organization for Economic Co-operation and Development (OECD), which appealed for an inclusive approach to the development process supported by adherence to the local ownership principle. Namely, in 1996, the OECD determined that sustainable development must be 'locally owned' (Reich, 2006: 27), and in that time the term "country ownership" was also used. Since then, an increasing number of donors and multilateral agencies have taken into account local ownership, although it has to be noted that there is often a gap between intentions, implementation, and real impacts (Schirch and Mancini-Griffoli, 2015: 127).

Therefore, it may be necessary first of all to highlight its functioning, because in response to the challenges of the new millennium, many donors and multilateral agencies have emphasized their commitment to and respect for the local ownership principle. This principle provides balance of power between external and domestic project partners, but also ensures the effectiveness of international development and peace initiatives and organizations in post-conflict and transitional countries. Respecting local knowledge, local customs and traditions, as well as the involvement of local implementing actors, has been proven to be an important factor of such projects' successes.

However, local ownership is not the ultimate goal, but rather the means to achieve another, probably bigger and more important goal, to democratize and legitimize the state-society relationship. Local ownership is a principle that guides foreign assistance, respecting the needs and priorities of the country's population that will receive such assistance (United States Institute of Peace, 2011). The respect for local ownership ensures greater efficiency and sustainability of peacebuilding activities, as this reduces the potential for resistance from local actors when they themselves have the role of creators of solutions best suited to local conditions (Wong, 2013: 47-57).

Experience has shown that such activities are unsustainable if they have been fully conceived by external actors, even when the implementation was undertaken primarily on a local level. Instead, local stakeholders must be involved in the creation and decisionmaking process so that the entire enterprise can function more durably. Of key importance for long-term sustainability is that efforts to transform conflicts are locally conceived, guided and implemented (Reich, 2016: 8).

It is important to note that the United States Agency for International Development (USAID) (also active in Serbia) has been undertaking measures since the very beginning of the 2000s to ensure that, in the countries receiving aid, local authorities, civil society and the people themselves (ordinary citizens) are not just passive receivers and implementers of US development programs. Local ownership is a true, if not the sole, way to ensure a long-lasting and sustainable change for the better. The receiving 
countries may receive food, medical supplies, various goods and services, financial resources, technical assistance, etc, but in that way, self-confidence and responsibility for their own future will never manifest itself. Local ownership improves the effectiveness of these assistance programs, as it hands over the decision making opportunity to local citizens (Kaplan, 2013). Local actors in the final instance must be trained and made responsible for the development of their own communities.

It is easy to speak theoretically about local actors, locally interested partners and/or users. But how can one determine who such users and/or partners would be? This is a key issue for the local ownership principle, pointing to the difficulties in identifying local partners to be engaged by international actors. It is indeed necessary to define who will be chosen as local partners in each individual case, and, in particular, how they are to be identified, how to negotiate their participation in ownership, and how and when they will take the lead in the whole process.

Multiple such criteria have been identified, e.g. "reflecting the diversity of society by being composed of a multi-ethnic, gender-balanced team", "being rooted in the country", "showing own initiative", "having an existing organizational infrastructure" or "explicit commitment to democratic principles and nonviolent conflict transformation". It is also stated that peace building interventions can quantitatively expand local ownership implementation, for example, by including previously excluded social groups (Schirch and Mancini-Griffoli, 2015: 127). There are three additional criteria to be added: Whether and how much (proposed projects, interventions, activities) affect the empowerment of the local population; whether these interventions/projects/activities contain a component of cultural sensitivity; and whether there is a long-term commitment to specific goals on the part of local actors.

All of them are rationally formulated, but these criteria for the selection of local actors and the localization of donor activities actually also reflect a pro-Western perspective, which is then essentially imposed as universally valid and transferrable. There is nothing wrong with that, but it must be clearly stated that, in fact, the first step in this process, i.e. the selection of local partners, actually reflects the principles, values and interests of foreign partners. This includes, among other things, decision-making (which often happens abroad), about who can be a user of resources and support, which thus creates a definitive change of power in local conditions.

Understanding local ownership can be understood in accordance with its other functions, e.g. it sometimes only emphasizes the political attitude or critiques the paternalistic attitudes of donor states toward local actors. One function is in the form of a political ideal that aims to convince policy- and decision-makers in donor countries about the existing fair, politically correct intentions of international agencies. These agencies will implement projects in cooperation with external and internal actors in the situation of urgent need, often causing deep social changes of existing local structures and practices. The proposed programs aim to convince stakeholders about the importance and usefulness of the planned activities. That is why the notion of local ownership is both pretentious and somewhat controversial, since it can conceal the omnipresence of asymmetric relations in power and authority between foreign and local actors. It is clear that the current practice in international cooperation implementation, whereby programs are financed from abroad, i.e. by Western countries, sets out a plan of action with more or less far-reaching consequences that are not always in line with the requirement to be adapted to the needs and demands of local actors in the region. 
The term 'local' ownership can sometimes seem unjustified and counterproductive, because it also can lead to excessive and unrealistic expectations from local actors (e.g. "we are here to provide ideas and you to give us money") and, consequently, lead to disappointment in terms of the realities of cooperation with foreign actors. We must bear in mind the fact that the goal of development is precisely the necessity of changing the previously existing local, non-democratic, hierarchical, often discriminative, misogynistic and homophobic, despotic structures. These previously existing structures have contributed to the accumulation of local problems, due to which the intervention of foreign actors became necessary. Therefore, a message that can be transmitted by the term "local ownership" may misleadingly imply that everything will remain the same as before, only supported by generous foreign finance, what is not actually possible and also poses difficulties for the achievement of development goals.

\section{LEARNING SITES}

Learning sites is perhaps more practical than the principle of local ownership and, therefore, a more appropriate concept of learning local traditions, customs and mentalities that refers to the knowledge of local conditions, relationships and other specificities, which diminishes the effect of the patronizing, intrusive donor relationship to those who receive assistance (Reich, 2006: 27).

The concept of "learning sites" should logically and substantially precede the application of the local ownership principle and be its framework for all stages and phases of the project. In doing so, space and time are provided and clearly allocated, in order to enable stakeholders and actors to collect project-related issues, with latent conflicts and personal disagreements, and to ask for clarifications on the issues that arise during this process. Such a place of learning may not really serve to achieve greater local ownership of the project, but it can certainly achieve greater transparency and deeper understanding (and therefore learning) of the basic structural problems in the project partnership.

The concept of learning sites is proposed in the discussion of local ownership as a logical preceding phase, with hope that it can contribute to the dismantling of what is often represented as a relationship between the patron and the client, between the donor and recipient, in international projects relating to the transformation of post-conflict societies. In order to develop this framework, the use of the notion of local ownership should first be problematized and analyzed in relation to the process of transformation of the conflict society into a post-conflict one.

Although learning sites as an experience is currently more applied in the work on projects at the level of NGOs, and not in terms of the cooperation of bilateral or multilateral actors, it will inevitably climb up to this 'higher' governmental level. The reason for this is that, today, not only increased participation, but also complete 'ownership' of the process of social change is required in order to ensure and guarantee efficiency and sustainability. In this process, the question remains as to whether to strive for a truly equal partnership, or even the utopia of true local ownership, given the inevitable inequalities present in current financing practices (Reich, 2016: 10). It should not be forgotten that both knowledge (theory) and public policy are formed from the same material, and that is language. Those who do not emphasize their own knowledge, do not have their own politically built discourse, do not "speak" their own theory, inevitably remain unnoticed and without influence. 


\section{THE CASE OF SERBIA}

The gender equality mechanisms in Serbia were part of international organizations' package of influences over the processes of democratic institutional reforms. As such, these were accepted by Serbian authorities and the state's institutional system in the process of democratic changes at the beginning of the 21st century. As all such international organizations active in Serbia were dominated by the policies of Western countries, their activities comprised all segments of the well-known 'Western' values of 'privatization', 'market-oriented economy' and 'democratization', which are consistently spread throughout the world (Majstorović, 2013: 199). Institutions established under such influences are not only organizational structures, but also adopted ways of thinking and acting (Abeles, 2014: 175).

Interventions of these organizations in the area of gender equality relied on a large number of international documents (primarily those created by the UN, EU and OSCE), which encourage and justify the establishment of institutional mechanisms for gender equality at all levels of government: state, regional, and local. These international documents guarantee a standardized functioning and (attempted) implementation of gender equality mechanisms. Furthermore, the high reputation of international authority, as well as the foreign experience of the countries from which the managers of these programs come from, which guarantees practical applicability, is a factor which is highlighted. These effects are reflected and materialized in certain, concrete institutional changes; that is, the successful formation and continuous functioning of new institutions, among which, as the most important, were the adoption and application of the following four mechanisms: 1) the quota electoral system (Mršević, 2007: 21), 2) the establishment of institutional gender equality bodies (Mršević, 2011: 104), 3) adoption of National Action Plans (2010 - 2015 and 2017 - 2020) for the implementation of UNSC Resolution 1325, and 4) introduction of gender equality in the security sector (Mršević and Janković, 2017: 240).

All of these institutional structures, collectively named gender equality mechanisms/ institutions were not genuine in origin, nor autochthonous, nor authentic in Serbia. Namely, these institutions existed and were developed previously in a number of European and other countries, and can therefore be considered a part of globalization trends and influences. It is impossible to argue that globalization has not affected Serbian society and its institutions, including those which promote gender equality. The external influences thus undoubtedly exist, and it is also certain that such influences have played a decisive role in the formation of these mechanisms. It should be emphasized that none of these mechanisms (e.g. a quota electoral system in Serbia as the first significant institutional change in the field of gender equality) were introduced by force, either under any external pressure or as a result of any external interventions of imperative character.

The influences of globalization upon the formation of gender equality mechanisms in Serbia did not occur in the form of the imposition of foreign institutional patterns and values, nor would such a 'hard' approach be accepted in a wider long-term and sustainable context. The impacts of this were preceded by the processes of so-called 'soft' influence of globalization changes within the international environment that contributed to the creation of a social climate of respect for gender equality and an increased visibility of women's political activities. The efforts of Serbian authorities to portray Serbia as a no-longernegative European example and a permanent exception also played a role, and their political will was to catch up with regional and international standards (Mršević and Janković, 2017: 240). 
Soft influence means any use of power that does not involve the use of force, which involves the absence of commands, and instead the use of convincing discourse based on the experience that a powerful narrative is always the best source of power. This soft power is - above all - of a discursive type, and utilizes the attractiveness of culture and values in order to increase the conviction of foreign influences (Naj, 2018: 17). Along with these soft influences, there was also a clear openness of society in Serbia and its institutions to accept such influences, considering them as authentic democratization elements of European integration processes.

Soft influences allow two-way exchange. The fulcrum for this can be respect of the local ownership principle by external actors and affirmation of that principle by internal actors. Local ownership often includes involvement of and cooperation with nongovernmental organizations and independent experts, rather than only bilateral or multilateral state actors (Mršević and Janković: 2017). Problems that occurred during the implementation of this program in Serbia within international organizations at the beginning included an occasional lack of sensitivity for gender issues on the side of certain foreign program managers, both female and male. Such behaviour can be identified as a specific manifestation of transnational patriarchy at work. From time to time, this can occur in the form of a certain low evaluations of the gender equality program as allegedly "overly/unrealistically demanding", "feminist" and allegedly "unnecessary" ("... isn't there already enough gender equality in Serbia?"), or of lower importance or priority for the international organization involved and Serbia ("... aren't there any major problems in Serbia to which resources should be directed?"). Therefore, the principle of local ownership was, in fact, not applied, either fully, or with confidence in the necessity of such respect, while the practical application of the concept of learning sites was completely absent with regard to the introduction of gender equality mechanisms.

But the chance to take advantage of the concept of local ownership has not only been disabled by foreign actors, rather it simply was not considered to be required or utilized by domestic, internal actors. In Serbia, genuine gender equality mechanisms did not previously exist. But this was likewise the situation in many other European countries, which also mostly imitated the Scandinavian experience when establishing their gender equality mechanisms. Moreover, in Serbia an environment existed in which many domestic values developed over preceding decades were simply ignored to the extent of total oblivion upon the arrival of international organizations. We cannot only lay the blame for this upon the external actors, because internal actors such as experts, scientists and NGO activists could and should have affirmed existing domestic values and practices, such as 'development as a means of meeting human needs', 'equality of women and men', 'the human being as the highest value', 'foreign political engagement through the NonAligned Movement', as well as the powerful, decades-old sense of anti-colonialism. It should also be added that a fostering of a sense of social justice and social equality had also been instilled in society over previous decades. Likewise, the ideology and mantra of 'Brotherhood and Unity' as a means of living in multiethnic society - specific to Yugoslav socialism - and workers' self-management in industry, should not be ignored. Based on these grounds, former Yugoslav society evolved with the widely shared conviction that social progress was secured, and that there was a predictable flow of agency over time. Factories, universities, roads were created during socialism, and women earned the right to participate in the labour market, and receive paid employment outside the domestic sphere. 
Additionally, the emancipatory heritage of socialism witnessed significant progress in terms of education of women to date (Majstorović, 2013: 102 and 214).

Feminist scholarship in Serbia during the previous decade, which increased in quantity, influenced democratic changes, proving the existence of specific gender aspects of conflict and gender-related reconciliation, but was tacit at the beginning of the 2000s when the activities and influences of international organizations in Serbia began. And when such works appeared, they essentially existed in a parallel reality, without affecting the activities of international organizations engaged in Serbia. Inclusion of gender issues too often emphasizes the differences, at the expense of locally owned values, but not the similarities between 'us' - the locals - and 'them' - the foreigners.

Because of this, concrete practices contained only token respect for the local ownership principle, most often in the form of a very small, almost symbolic presence of local knowledge. It is arguably best to say that it was not local knowledge but often local ignorance, due to the fact that the 'local expertise' that was included was often the opinions espoused by young (and low-level) domestic program clerks and assistants to foreign program staff. This is the result of two primary factors: First, it was easy to obtain such opinions through in-office discussions and interviews, and second, such opinions were superficial in nature, and could be easily moulded to conform with attitudes of their (foreign) superiors, making them, on the whole, 'acceptable' to foreigners. Because these superiors came almost exclusively from Western countries, and their Western imagination still holds the 'otherness' of the Balkans as being 'chauvinistic, abnormal and with nationalist tendencies', 'permanently transiting' toward, but never fully reaching, Europe and European prosperity (Majstorović, 2013: 202 and 205) .

The manner of formally respecting the principles of local ownership in these postconflict processes mainly manifested itself in the sporadic, irregular participation of representatives of domestic women's non-governmental organizations and professionals of different profiles (Tarnaala, 2016) in conferences, round tables, panel discussions, and similar. The marginalized character of the local participants in these processes is confirmed by the fact that those involved in the creation of gender equality mechanisms remained within the limits of the role of transmission of the 'foreign knowledge' of Western countries, and, later, the role of the users in their local application.

Neither the Center for Women's Studies, as the presumed leading local theoretical think-tank, nor prominent women's non-governmental organizations, ever drew attention to discursive, descriptive, or even any theoretical knowledge of local ownership principle existence and functioning. Until recently, in fact, domestic production of knowledge has been continuously lacking in terms of the need for implementation and in the concrete functioning of the local ownership principle, particularly within gender equality programs, and therefore in the establishment of gender equality mechanisms. Foreign actors failed to inform the local scene, and local actors, intellectually sufficiently capable of independently reflecting on the meaning, importance and application of the local ownership concept missed a historic opportunity to do so by building their own discursive strategies for achieving local influence.

Therefore, there happens no essential "localization" of gender equality mechanisms based on domestic knowledge, i.e. their creation and colouring with local feminist knowledge, experience, local feminist theory and local pride in their own feminist tradition and achievements. And dealing with feminist theory and the conduct of feminist research did not proceed any further in the direction of a specific request addressed to 
international actors to respect and apply the concept of local ownership, although, in terms of program design and implementation, they were - in fact - mandatory. In the situation of abandoning local efforts to promote and understand the significance of the local ownership principle, the measure of its implementation has remained a discretionary assessment by international actors, as not always being particularly willing to empower their local partners and to potentially create complications for their own work(load).

\section{GLOBALIZATION AND THE HUMANITARIAN INDUSTRY}

Gender-based power shapes all human relationships, including especially political power. Political inequality has been identified as the central public relationship of power between men and women, and such a lack of political equality is particularly emphasized in post-conflict societies. Some authors (Tiesen, 2015: 85) use terms such as 'fragile', 'unstable', 'incomplete', because these societies are in a situation where they have a primary need for urgent humanitarian aid, 'pacification' and 'normalization', and the establishment of a new beginning (Abeles, 2014: 277). Namely, the 'fragile state' is the definition of a post-conflict country with low incomes and poor governance, leaving its citizens in an uncertain social, political and economic context. Almost everywhere the topics are identical (environmental protection, anti-corruption mechanisms, the socioeconomic-political position of women, democratization of institutions, etc.), and part of that package is the affirmation of the idea that women should be given the possibility of autonomous status and professional affirmation. The establishment of gender equality institutions is usually preceded by, politically and financially supported from the outside, the proliferation of a network of non-governmental organizations dealing with different aspects of gender equality, violence against women, political participation of women, the fostering of women's artistic creativity, economic independence of women, participation of women in the security sector, etc. From the standpoint of international organizations, the creation of NGOs acted as a guarantor of the emergence of a genuine civil society, all in the name of the principle that the greater the number of NGOs, the more democratic the society (Abeles, 2014: 278). But this issue did not only affect NGOs; also, local authorities became aware that they stood in line to receive international funds were they to place an emphasis upon gender equality activities.

According to the views of international agencies, such situations require an accelerated, even "feverish process of democratization", implying urgent education on market laws, the training of managers (Abeles, 2014: 277), and institutional reform and democratization. In fact, there was no need for hurry, and even less for a 'feverish' approach, and this was essentially dictated only by the justified (but also unjustified) fears of international actors that they would be left without funds for the long-term running of their own programs. Since projects usually last only six months to one year, they are unlikely to lead to more permanent, sustainable changes, as real and lasting institutional changes generally require decades; not months or years. Therefore, a common challenge for all international actors is irregularity and the lack of donors' financial resources to "think and plan for decades" with regard to their programs within a particular country or region. This is why, if there is a true motivation for sustainability, aims and efforts can only be achieved through local ownership: National dialogues and platforms allow local ownership to be the basis for building trust and security between domestic and foreign actors (Schirch and Mancini- 
Griffoli, 2015: 124), but often overlook it, as they simply "do not have time" for it. What has not happened, at least in terms of feminist theory and the feminist movement of Serbia, regarding the mechanisms of gender equality is the critical deciphering of such a 'humanitarian industry' (Abeles, 2014: 277), with the consequence being that the opportunities provided by the local ownership principle have gone ignored.

With such interventions of the 'humanitarian industry' being repeated across the globe many times over, one can really change the political space of a society by amnestically erasing various local and pre-existing features. Manufacturers of knowledge have the power to make this 'generally accepted' knowledge. However, there remains an open question as to the longevity and sustainability of these changes so that, in this respect, local ownership can act as a fulcrum through which to provide them with local acceptance.

\section{THE 'GLOCAL' PERIOD ${ }^{1}$}

The term 'global' means the attainment of a level of integration and interconnection, belonging to the global world, regardless of cultural identity and place in a certain territory. Globalization as a multi-dimensional process transforms the network of relationships between the individual and the collective, and humanity's way of thinking and acting changes deeply throughout the planet (Abeles, 2014: 6 and 7).

The increasingly intense globalization trends of the last quarter of the twentieth century represent not only an environment of strong economic and political influence, but also an environment in which significant changes arose in the spread of institutionalized gender equality practices in countries where they were previously non-existent. Globalization opens a new era that is inherent, and a new set-up of the principles by which social life and the world's order are organized. A new face of society is reflected, whereby, in the processes of homogenization and standardization, the boundaries between original, traditional and locally understood cultural values are increasingly blurred. Boundaries and distances are no longer obstacles, the consequences being that, for example, across the globe people eat almost the same food, dress in the same clothes and listen to the same music (Abeles, 2014: 44, 45 and 52). And it is not too much to say also, that this includes women's demands for the same rights, from institutional protection against gender-based violence, through political parity, to raising the general level of gender equality in all social and private aspects. It is clear that globalization changes not only economic relationships, but also the configuration of traditional power relationships. Women, women's movements, women's groups, experts and activists increasingly communicate and cooperate on a global level. The emphasis of the modern world is placed on an intensification of all such flows and an acceleration of exchanges (Abeles, 2014: 16 \& 17), and within this exchange gender equality concepts have their place.

Therefore, there are authors who argue that we have stepped into the so-called 'glocal' period (Abeles, 2014: 135), where deeper mixing and interweaving of local and global concepts occurs. Namely, the key determinant of the modern world is constant circulation. Globalization can be defined as an acceleration of the flow of capital, human beings, goods, images and ideas, and the concept of gender equality institutions/mechanisms. No longer are traditional geographical and political boundaries to be considered obstacles. Such

\footnotetext{
${ }^{1}$ Terminology taken from Antropologija globalizacije, by Marc Abeles.
} 
movements and networks result in a change in social and cultural characteristics. It is true that gradually a peripheral culture will increasingly assimilate the imported meanings and shapes, and will become increasingly similar to that of the centre. Such a removal of differences contributes to the growing global homogenization and standardization (Abeles, 2014: 41, 43 \& 44). But this does not remain forever a one-way movement from the centre to the periphery. The periphery also has the power to articulate knowledge of itself, and that knowledge is equally accepted as were it to have originated in the centre, though perhaps not with the same (self-)evaluated capacity and penetration. Nevertheless, there are needs and ways in which the voices of different actors within a society can influence reform processes in the field of security and gender equality (Welch, Gordon \& Roos, 2015: 3).

The key element of globalization is the fact that movement between the centre and the periphery is not only one-way, but also involves very different two-way circular flows with different outcomes. The facts disprove the image of a planet subjected to ever-present oneway processes of homogenization, standardization and, by default, Westernization. Cultural globalization is a more complex issue than at first appears. All of these elements are found in a continuous circle from one end of the planet to the other (Abeles, 2014: $51 \&$ 52). The centre increases its influence over the periphery, which in turn strives to reach the centre. The centre, which comprises the industrialized Western countries, uses intensive capitalist production of goods that are sold all over the world. The task of the periphery is to provide cheap raw materials and labour to the centre, but also to adopt the same - or at the very least a similar - system of values and beliefs that would simplify and facilitate the initial process. But it also makes control of the centre easier. Technological innovations in communications and transport in global frameworks have produced new forms of consumption (Abeles, 2014: 31 and 33) of both goods and ideas, and movements and directions of thought, methodology and values.

In the dichotomous centre:periphery pattern, the hegemony of rich countries stands as the core feature. With globalization, certain issues have become indispensable, above all those concerning the status of politics and changes that are experienced by nation states (Abeles, 2014: 118 and 122). Globalization can therefore be understood as a form of cultural imperialism and as an inevitable process of homogenization aimed toward the ease of influence and control from the centre. But the circulation of cultural products does not allow the exclusion of homogenization: All these elements are found in continuous circulation the world over (Abeles, 2014: 47 \& 52). Global diversity can be understood today only if one takes into account interconnections and interdependencies. Awareness of interconnectedness increasingly affirms the view that it is necessary to allow other voices to be heard, and not only Western ones, which have thus far been undisturbed in their dominance (Abeles, 2014: $107 \&$ 115).

In an open world, not only individuals and groups circulate, but also information and knowledge in all possible ways: Between the centre and periphery there is a more or less open circulation of mockery, parody and pastiche. The presence of a global institutional culture is, by its very nature, mostly patchworked, where the most diverse meanings and practices are intertwined. Social formulation of difference is a complex and continuous process of negotiation in which hybrid social forms are manifested. Gender regimes, as with stereotypes, circulate to contribute to global gender mainstreaming, resulting in significant political consequences (Abeles, 2014: 101, $102 \& 161$ ).

We argue that the inclusion of local knowledge in implementing the local ownership principle in the 'glocal' era in Serbia, the so-called 'deep democracy', did not happen. 
External influences were predominant. Such 'deep democracy' would have evolved into a multidimensional space where the locally and globally harmoniously intermingled (Abeles, 2014: 274). The term is used to describe such a type of experience, rooted in the local and nearby environments, as well as the ability to receive and accept broad influences beyond the borders of states and continents. If external influences are always - and exclusively asymmetrically -prevalent over domestic ones, then we lack both established deep democracy and respect for the local ownership principle.

\section{CONCLUSION}

Other countries' experiences suggest that international donors and foreign governments often underestimate local capacities to contribute to change, but as is not uncommon, the same international actors simultaneously ironically complain about the lack of local ownership (Schirch and Mancini-Griffoli, 2015: 120). At the same time, civil society equally regrets that foreign governments and international donors overlook or underestimate their abilities. Both reactions failed to manifest themselves in Serbia when establishing gender equality mechanisms, as foreign actors were satisfied with the level of cooperation of lesser local actors that was achieved. And for their part, they did not emphasize requests for local ownership because they did not even know that this was possible, or did not have an interest in true local affirmation. On the domestic scene, the impression was given that there was no awareness that women's movements often sank into oblivion after short-term victories, after which these short-lived triumphs were replaced by long-lasting silences (Sklevicky, 1996: 74).

The initial lack of local feminist knowledge in some areas has been largely automatically and too easily in-filled by foreign, Western experiences, theories and practices.At worst, there has been a tendency toward the continuation of patriarchal traditions represented by local male political elites, uninterested in gender equality. This has particularly been the case in (near-)exclusively male professionally privileged domains, for instance the security sector.

We argue that both foreign and domestic actors are responsible for such a situation. Foreign actors because, apart from Western theory and experience, they failed to acquire and/or disregarded local knowledge, considering it either non-existent or inferior to that of Western countries. The concept of learning sites was not, however, applied in practice in Serbia. At the same time, domestic actors were satisfied with the comfortable position of the well-chosen transmitters and users of imported knowledge and practice, without trying to understand the possibilities that the local ownership principle offered, and failing to even pretend to have the role of either creators or owners of relevant facts and experiences.

Perhaps in Serbia, then, the winning combination would be so-called transversal policy. Namely, the specific form of coalition policy that Yuval Davis terms transversal policy, requires that the form and content of particular feminist struggles should be determined and framed by concrete historical conditions. The function of transversal policy is to open the way for mutual support and greater efficiency in the struggle for a less sexist, less racist and more democratic society in permanently changing contexts in which we live and act (Kolarić, 2011: 115-116). Having perceived and accepted different parts and histories of themselves, it should be a part of feminist critique to believe that 
things can change and that history and oppression should not always be repeated (Majstorović, 2013: 215).

The need to create knowledge about gender equality in Serbia was obvious, and likewise there was a former - but also present - need to create a scientific space that would contribute to the development of contextual awareness (Jakšić, 2016). Or, to put it briefly, it was necessary at the beginning of the twenty-first century to be smarter than we once were, because, for the application of the concepts of transversal policy, deep democracy and an insistence on the application of the local ownership principle in relations with foreign actors, it can never be too late. The smart mind is never superfluous, neither now, nor in the future.

\section{REFERENCES}

Abeles, Mark. 2014. Antropologija globalizacije. Beograd: Biblioteka 20. vek.

Jakšić, Ana. 2016. Prikaz knjige Poluperiferija i rod: pobuna konteksta. P.U.L.S.E. magazin.

Kaplan, Melissa. 2013. Local ownership: Who what and how. Devex - International Development News.

Kolarić, Ana. 2011. „Жена, домаћица, мајка. Од те три речи зависи цео свет” analiza časopisa Žena(19111921). u: Knjiženstvo, časopis za studije književnosti, roda i kulture. godina I broj 1.

Majstorović, Danijela. 2013. Diskursi i periferije. Beograd: Biblioteka XX vek.

Mičić, Maja. 2016. Standardi i uloga Organizacije za evropsku bezbednost i saradnju (OEBS) u vezi sa ostvarivanjem rodne ravnopravnosti $u$ državama članicama. Univerzitet u Novom Sadu: Asocijacija centara za interdisciplinarne i multidisciplinarne studije, Centar za rodne studije.

Mršević, Zorica. 2001. Ka demokratskom društvu - Rodna ravnopravnost. Beograd: Institut društvenih nauka.

Mršević, Zorica. 2007. Ka demokratskom društvu - sistem izbornih kvota. Beograd: Institut društvenih nauka.

Mršević, Zorica. i Janković, Svetlana. 2017. Primena principa lokalnog vlasništva: od viktimizacije do osnaživanja žena, Temida, vol. 20, br. 1, str. 23-44.

Mršević, Zorica. i Janković, Svetlana. 2017. Mehanizam za rodnu ravnopravnost kao deo globalizacijskih trendova. u: Globalizacija i izolacionizam, ur. Vukotić Veselin i Šuković Danilo, Beograd: Centar za ekonomska istraživanja Instituta društvenih nauka.

Naj, Džozef. 2018. Meka i oštr moće Kine. Danas, 19. januar, str.17.

Reich, Hannah. 2006. „Local Ownership“ in Conflict Transformation Projects Partnership, Participation or Patronage? Berghof Occasional Paper. No. 27 September.

Schirch, Lisa. and Deborah, Mancini-Griffoli. 2015. Local Ownership in Security: Case Studies of Peacebuiiding Approaches. The Hague: Alliance for Peacebuilding, GPPAC, Kroc Institute.

Sklevicky, Lydia. 1996. Konji, žene, ratovi. Zagreb: Ženska infoteka.

Tarnaala, Elisa. 2016. Women in Armed Groups \& Fighting Forces: Lessons from Gender Sensitive Disarmament, Demobilization \& Reintegration Programmes, Oslo: Norwegian Peacebuilding Resource Centre (NOREF).

Tiessen, Rebecca. 2015. Gender essentialism in Canadian foreign aid commitments to women, peace, and security. International Journal, Vol. 70(1) str.84-100.

United States Institut for peace. 2011. USIP „Peace Terms“ Glossary.

Welsh Cleland, Anthony. Gordon, Eleanor. \& Roos, Emmicki. 2015. Security Sector Reform and the Paradoxical Tension between Local Ownership and Rod Equality. Stability: International Journal of Security and Development. 4(1), p.Art. 53.

Wong, Pearly. 2013. „Local Ownership“ in Peacebuilding - a Premature Rhetoric? United Nations Peace and Progress. Volume 1 (1), str. 47-57.

Yuval-Davis Nira. 1985. „Front and rear: The sexual division of labor in Israeli army“. Feminist Studies 11/1985, str. 663 .

Yuval-Davis Nira. 1997. Gender and Nation, London: SAGE Publications. 


\section{LOKALNO POZNAVANJE PRINCIPA LOKALNOG VLASNISTVA U SRBIJI}

Predstavljen je način funkcionisanja i implementacije principa lokalnog vlasništva u situaciji nedostatka podrške lokalnog znanja. Mehanizmi rodne ravnopravnosti bili su deo paketa uticaja međunarodnih organizacija na proces demokratskih institucionalnih reformi u Srbiji. Ceo proces se odnosio na veliki broj međunarodnih dokumenata koji podstiču i opravdavaju uspostavljanje institucionalnih mehanizama za rodnu ravnopravnost na svim nivoima vlasti: nacionalnim, regionalnim i lokalnim. Iskustva i znanje zapadnih zemalja najviše je doprinelo procesu formiranje mehanizama rodne ravnopravnosti i njihovo kasnije funkcionisanje. Nedostatak produkcije lokalnih znanja pre svega o suštini $i$ ulozi principa lokalnog vlasništva u stvaranju institucija za rodnu ravnopravnost, je trajna u Srbiji. Proces „učenje mesta“ tj. upoznavanje spoljašnjih aktera sa unutrašnjom situacijom, praktično se nije primenio u Srbiji. Takozvani „,glokalni“ period dubokog prožimanja lokalnog $i$ globalnog se nije dogodio. U tekstu se argumentovano zastupa stav da nije postojala suštinska „lokalizacija" mehanizama rodne ravnopravnosti zasnovana na domaćem znanju $i$ da su za tu situaciju odgovorni $i$ strani i domaći akteri. Spoljašnji, jer osim zapadne teorije $i$ iskustva, ne znaju ilili zanemaruju lokalno znanje, bez obzira da li ga smatraju nepostojećim ili inferiornijim od znanja zapadnih zemalja. Istovremeno, domaći akteri su se prebrzo zadovoljili udobnoм pozicijom sekundarno važnih aktera, samo sa ulogom odabranih prenositeljki/ka $i$ korisnik/ca inostranih koncepata. Oni nisu iskoristili mogućnosti koje pruža princip lokalnog vlasništva i nisu ni pretendovali da zauzmu ulogu stvaraoca, niti ulogu relevantnih vlasnika znanja $i$ na njemu zasnovanih javnih politika i praksi.

Ključne reči: međunarodni akteri, lokalno poznavanje principa, programi učenja, humanitarna industrija, mehanizmi rodne ravnopravnosti u Srbiji, transverzalna politika.

Proofreading and copy-editing:

Andrew Lawler 